\title{
SURAT KUASA MEMBEBANKAN HAK TANGGUNGAN (SKMHT) DALAM PERJANJIAN KREDIT PERBANKAN DI KOTA DENPASAR Oleh
}

I Putu Deny Wiryanta*I Ketut Mertha**I Made Puryatma***

Program Magister Kenotariatan Universitas Udayana

Email : iputudenywiryanta@yahoo.co.id

\section{PROCURATION OF ENCUMBRANCE RIGHT CHARGING (SKMHT) ON BANKING LOAN AGREEMENT IN DENPASAR CITY}

The Law No. 4 of 1996 on Encumbrance Right (UUHT) aims to provide a foundation that enabling enactment of a powerful Encumbrance Right institutions, including the position of Procuration of Encumbrance Right Charging (SKMHT). In Article 15, Paragraph (3) and (4) UUHT declared a period of time for SKMHT for land rights were already registered and not registered yet. In fact, losses experienced by the debtor often occur as a result of that provision. The losses were partly a result of the expiration of SKMHT because of Encumbrance Right Deed (APHT) getting process had been exceeded the period of SKMHT validity, so that creditors do not have yet a certain guarantee binding deed of the guarantee provided by the debtor, which resulted in the arrest of the funds that will be allocated to debtor and the debtor it is becoming difficult to practice business activities. Based on this problem, the problem that can be formulated is how the legal result of the implementation of the Procuration of Encumbrance Right Charging (SKMHT) in banking loan agreement and What are the constraints in the implementation of the Procuration of Encumbrance Right Charging (SKMHT) in banking loan agreement as well as how to overcome the efforts in particular in Denpasar City.

This type of research used in this thesis is empirical legal research with the consideration that the starting point of the research is the analysis of the gap between das sein sollen and the effectiveness SKMHT in which the banking loan agreement whereas SKMHT regulated under Article 15 UUHT. In Article 15, Paragraph (3) and (4) UUHT declared a period of time for SKMHT to land rights were already registered and not registered. In fact,losses experienced by the debtor often occur as a result of that provision. The losses were partly a result of the expiration of SKMHT because of Encumbrance Right Deed (APHT) getting process had been exceeded the period of SKMHT validity.

The resultsof research areeffortsundertakento overcomethese obstacles, by renewingSKMHTwhichhas expired. Thus, overcomingbothof these obstaclesis only can be done byrenewingSKMHTwhile waiting the certificating process ofunregistered SKMHTobject. Once thecertificate of land rightis issued, thenbasedon SKMHT, the encumbrance right charging of SKMHT object is done so it became the object of encumbrance right.

Keywords: effectiveness, Encumbrance Right, Procuration, Period, Agreement.

\section{PENDAHULUAN}

Kebutuhan akan dana saat ini semakin meningkat, seiring dengan pesatnya perkembangan dunia usaha di Indonesia. Dana merupakan salah satu modal yang digunakan oleh pengusaha untuk mengembangkan usahanya. Seiring dengan perkembangan tersebut, maka tidak jarang pengusaha maupun masyarakat memanfaatkan fasilitas kredit yang diberikan oleh bank. Salah satu syarat untuk menikmati fasilitas kredit tersebut adalah adanya jaminan, yang digunakan untuk pelunasan apabila masyarakat sebagai debitur lalai dalam memenuhi kewajibannya (wanprestasi).
Mengingat pentingnya dana perkreditan tersebut dalam proses pembangunan, sudah semestinya jika pemberi dan penerima kredit, serta pihak lain yang terkait mendapat perlindungan melalui suatu lembaga hak jaminan yang kuat dan yang dapat memberikan kepastian hukum bagi semua pihak yang berkepentingan. ${ }^{1}$ Tanah sebagai jaminan untuk memperoleh kredit, tidak terlepas dengan Undang-Undang Nomor 5 tahun 1960 tentang Peraturan Dasar Pokok-Pokok Agraria yang selanjutnya disebut "UUPA" yang didalamnya mengatur tentang tanah. Dengan berlakunya

${ }^{1}$ Adrian Sutedi,2012, Hukum Hak Tanggungan, Jakarta, Sinar Grafika. Hal.93-94. 
UUPA pada tanggal 24 september 1960, maka hak jaminan atas tanah disebut dengan "Hak Tanggungan".

Tanah merupakan salah satu benda tak bergerak yang dapat dijadikan jaminan, sebagaimana diatur dalam Undang-Undang Nomor 4 Tahun 1996 tentang Hak Tanggungan Atas Tanah Beserta Benda-benda Yang Berkaitan Dengan Tanah (selanjutnya disebut UUHT). Undang-Undang Nomor 4 tahun 1996 tentang Hak Tanggungan bertujuan memberikan landasan untuk dapat berlakunya lembaga Hak Tanggungan yang kuat, diantaranya mengenai kedudukan Surat Kuasa Membebankan Hak Tanggungan (SKMHT). Dalam hal pemberi Hak Tanggungan tidak dapat hadir di hadapan PPAT atau Notaris, Pasal 15 Ayat (1) Undang-undang No 4 tahun 1996 memberikan kesempatan kepada pemberi Hak Tanggungan untuk menggunakan SKMHT.

Dalam memberikan Hak Tanggungan, pemberi Hak Tanggungan wajib hadir dihadapan Pejabat Pembuat Akta Tanah (selanjutnya disingkat PPAT). Pada asasnya pembebanan Hak Tanggungan wajib dilakukan sendiri oleh pemberi Hak Tanggungan, tetapi jika benar-benar diperlukan yaitu dalam hal pemberi Hak Tanggungan tidak dapat hadir dihadapan PPAT, maka ia wajib menunjuk pihak lain sebagai kuasanya dengan Surat Kuasa Membebankan Hak Tanggungan (selanjutnya disingkat SKMHT) yang berbentuk akta otentik. SKMHT diatur didalam Pasal 15 UUHT yang menyatakan: ${ }^{3}$

(1) Surat Kuasa Membebankan Hak Tanggungan wajib dibuat dengan akta notaris atau akta PPAT dan memenuhi persyaratan sebagai berikut:

a. tidak memuat kuasa untuk melakukan perbuatan hukum lain

2 Habib Adjie, 2008. Hak Tanggungan Sebagai Lembaga Jaminan atas Tanah, Bandung, Mandar Maju, hal. 6. ${ }^{3}$ Ibid. hal. 6. daripada membebankan Hak Tanggungan;

b. tidak memuat kuasa substitusi;

c. mencantumkan secara jelas obyek Hak Tanggungan, jumlah utang dan nama serta identitas kreditornya, nama dan identitas debitor apabila debitor bukan pemberi Hak Tanggungan.

(2) Kuasa Untuk Membebankan Hak Tanggungan tidak dapat ditarik kembali atau tidak dapat berakhir oleh sebab apapun juga kecuali karena kuasa tersebut telah dilaksanakan atau karena telah habis jangka waktunya sebagaimana dimaksud pada ayat (3) dan ayat (4).

(3) Surat Kuasa Membebankan Hak Tanggungan mengenai hak atas tanah yang sudah terdaftar wajib diikuti dengan pembuatan Akta Pemberian Hak Tanggungan selambat-lambatnya 1 (satu) bulan sesudah diberikan.

(4) Surat Kuasa Membebankan Hak Tanggungan mengenai hak atas tanah yang belum terdaftar wajib diikuti dengan pembuatan Akta Pemberian Hak Tanggungan selambat-lambatnya 3 (tiga) bulan sesudah diberikan.

(5) Ketentuan sebagaimana dimaksud pada ayat (3) dan ayat (4) tidak berlaku dalam hal Surat Kuasa Membebankan Hak Tanggungan diberikan untuk menjamin kredit tertentu yang ditetapkan dalam peraturan perundang-undangan yang berlaku.

(6) Surat Kuasa Membebankan Hak Tanggungan yang tidak diikuti dengan pembuatan Akta Pemberian Hak Tanggungan dalam waktu yang ditentukan sebagaimana yang dimaksud pada ayat (3) atau ayat (4), atau waktu yang ditentukan menurut ketentuan sebagaimana yang dimaksud pada ayat (5) batal demi hukum.

Dalam Pasal 15 Ayat (3) dan (4) UUHT dinyatakan suatu jangka waktu bagi SKMHT untuk hak atas tanah yang sudah terdaftar dan belum terdaftar. Dalam faktanya sering terjadi kerugian yang dialami debitur akibat ketentuan tersebut. Kerugian tersebut antara lain disebabkan kadaluarsanya SKMHT akibat dari 
proses mendapatkan Akta Pemberian Hak Tanggungan (APHT) yang melebihi jangka waktu berlakunya SKMHT, sehingga kreditur belum memiliki akta pengikatan jaminan yang pasti terhadap jaminan yang diberikan oleh debitur, yang berakibat penahanan terhadap dana yang akan disalurkan kepada debitur dan bagi debitur hal ini menjadi hambatan dalam menjalankan kegiatan usaha.

Sehubungan dengan latar belakang diatas maka menarik untuk dilakukan penelitian serta kemudian menuangkan dalam bentuk artikel ilmiah yang berjudul : "Surat Kuasa Membebankan Hak Tanggungan Dalam Perjanjian Kredit Perbankan”.

Berdasarkan latar belakang masalah diatas, maka dapat dikemukakan rumusan masalah sebagai berikut :

$\begin{array}{rrr}\text { 1. Bagaimanakah } & \text { akibat hukum } \\ \text { terlaksananya } & \text { Surat } & \text { Kuasa }\end{array}$

Membebankan Hak Tanggungan (SKMHT) dalam perjanjian kredit perbankan?

2. Apakah yang menjadi kendala dalam pelaksanaan Surat Kuasa Membebankan Hak Tanggungan (SKMHT) dalam perjanjian kredit perbankan serta bagaimana upaya dalam mengatasinya khususnya di Kota Denpasar?

Tujuan umum dari penelitian ini bertujuan untuk mengembangkan ilmu hukum, khususnya bidang hukum kenotariatan melalui pemahaman atas efektivitas Pasal 15 Ayat (3) dan (4) Undang-Undang Nomor 4 tahun 1996 tentang Hak Tanggungan mengenai Surat Kuasa Membebankan Hak Tanggungan (SKMHT) dalam perjanjian utang- piutang khususnya di Kota Denpasar. Adapun tujuan khusus yang ingin dicapai sesuai sesuai dengan permasalahan yang dibahas dalam penelitian ini, yakni :
1. Untuk mengetahui dan menganalisis bagaimanakah akibat hukum terlaksananya Surat Kuasa Membebankan Hak Tanggungan (SKMHT) dalam perjanjian perjanjian kredit perbankan khususnya di Kota Denpasar.

2. Untuk mengetahui Faktor-faktor penghambat pelaksanaan Surat Kuasa Membebankan Hak Tanggungan (SKMHT) dalam perjanjian kredit perbankan serta bagaimana upaya dalam mengatasinya khususnya di Kota Denpasar.

Jenis penelitian yang akan digunakan adalah penelitian hukum empiris dengan pertimbangan bahwa titik tolak penelitian adalah analisis dari adanya kesenjangan antara das sollen dengan das sein yaitu adanya kesenjangan antara peraturan-peraturan hukum tersebut dengan keadaan di masyarakat yaitu efektivitas SKMHT dalam perjanjian kredit perbankan.

\section{KERANGKA TEORI}

Teori Perlindungan Hukum

Awal mula dari munculnya teori perlindungan hukum ini bersumber dari aliran hukum alam yang dipelopori oleh Plato, Aristoteles, dan Zeno. Menurut aliran hukum alam menyebutkan bahwa hukum itu bersumber dari tuhan yang bersifat universal dan abadi, serta antara hukum dan moral tidak boleh dipisahkan. Para penganut aliran ini memandang bahwa hukum dan moral adalah cerminan dan aturan secara internal dan eksternal dari kehidupan manusia yang diwujudkan melalui hukum dan moral.

Menurut Fitzgerald, "Teori Perlindungan Hukum adalah hukum bertujuan mengintegrasikan dan mengkoordinasikan berbagai kepentingan dalam masyarakat karena dalam suatu lalu lintas kepentingan di lain 
pihak." ${ }^{4}$ Kepentingan hukum adalah mengurusi hak dan kepentingan manusia, sehingga hukum memiliki otoritas tertinggi untuk menentukan kepentingan manusia yang perlu diatur dan dilindungi. ${ }^{5}$

Perlindungan hukum harus melihat tahapan yakni perlindungan hukum lahir dari suatu ketentuan hukum dan segala peraturan hukum yang diberikan oleh masyarakat yang pada dasarnya merupakan kesepakatan masyarakat tersebut untuk mengatur hubungan perilaku antara anggota-anggota masyarakat dan antara perseorangan dengan pemerintah yang dianggap mewakili kepentingan masyarakat.

Menurut Satjipto Raharjo, "perlindungan hukum adalah memberikan pengayoman terhadap Hak Asasi Manusia (HAM) yang dirugikan orang lain dan perlindungan itu diberikan kepada masyarakat agar dapat menikmati semua hak-hak yang diberikan oleh hukum."6 Penerapannya pada pelaksanaan SKMHT adalah untuk memberikan perlindungan bagi para pihak dalam perjanjian utang piutang yaitu kreditor (bank) dan debitor pada penandatanganan perjanjian kredit dengan jaminan hak atas tanah terutama terhadap tanah yang belum terdaftar, oleh sebab itu dengan adanya SKMHT akan lebih menjamin keamanan masing-masing pihak sehingga tidak akan ada yang merasa dirugikan, bagi kreditor dengan ditandatanganinya SKMHT akan memiliki kewenangan hukum untuk nantinya menandatangani Akta Pemberian Hak Tanggungan (APHT) meskipun tanpa kehadiran debitor sebagai pemberi Hak Tanggungan dan akan dilindungi oleh hukum, serta memiliki kewenangan untuk mengeksekusi jaminan tersebut apabila terjadi kredit macet (Non Performing Loan), sedangkan bagi debitor

${ }^{4}$ Satjipto Raharjo, 2000, Ilmu Hukum, Bandung, PT.Citra Aditya Bakti .hal. 53.

${ }^{5}$ Ibid. hal 69

${ }^{6}$ Ibid. dengan ditandatanganinya SKMHT tersebut debitor juga akan memperoleh perlindungan hukum dan juga kepercayaan dari pihak kreditor (bank) karena telah memenuhi salah satu persyaratan dari 5C yaitu Collateral atau agunan yang secara otomatis permohonan kredit atau pinjaman dana tersebut dapat dicairkan dan dapat dipergunakan oleh debitor

\section{III.PEMBAHASAN}

\section{A. Syarat Sah berlakunya SKMHT}

Dalam penjelasan Umum angka 7 dan penjelasan Pasal 15 ayat (1) UUHT dinyatakan bahwa pemberian Hak Tanggungan wajib dilakukan sendiri oleh Pemberi Hak Tanggungan dengan cara hadir dihadapan PPAT. Hanya apabila karena sesuatu sebab tidak dapat hadir sendiri dihadapan PPAT, ia wajib menunjuk pihak lain sebagai kuasanya, dengan Surat Kuasa Membebankan Hak Tanggungan (disingkat SKMHT) yang berbentuk akta autentik.

Pembuatan SKMHT selain oleh Notaris juga ditugaskan kepada PPAT, karena PPAT ini yang keberadaannya sampai pada wilayah Kecamatan dalam rangka pemerataan pelayanan di bidang pertanahan. Isi SKMHT tersebut harus memenuhi persyaratan sebagai berikut.

- Tidak memuat kuasa untuk melakukan pembuatan hukum lain dari pada membebankan Hak Tanggungan

- $\quad$ Tidak memuat kuasa substitusi

- Mencantumkan secara jelas objek Hak Tanggungan, jumlah utang dan nama serta identitas kreditornya, nama dan identitas debitur apabila debitur bukan pemberi Hak Tanggungan.

Di dalam Surat Kuasa membebankan Hak Tanggungan terdapat dua aspek yang juga harus diperhatikan, yakni sebagai berikut: 
a. Pembatasan Isi/Muatan dalam SKMHT

UUHT secara tegas membatasi isi atau muatan dari SKMHT, yaitu hanya memuat perbuatan hukum membebankan Hak Tanggungan. Jadi tidak boleh membuat kuasakuasa melakukan perbuatan hukum lain yang bermaksud mendukung tercapainya maksud pemberian jaminan yang bersangkutan. Misalnya, tidak memuat kuas untuk menjual, menyewakanobjek Hak Tanggungan, memperpanjang hak atas tanah atau untuk mengurus perpanjangan sertifikat, mengurus balik nama dan sebagainya. Jika memang dikehendaki, hal-hal semacam itu dapat dimuat di dalam APHT, namun bukan sebagai kuasa tetapi hanya berupa janji-janji antara pemberi Hak Tanggungan dengan pemegang Hak Tanggungan $^{7}$ seperti halnya yang dimuat dalam Pasal 11 ayat (2) a sampai dengan k.

Selain itu, jika dalam Surat Kuasa Memasang Hipotik (SKMH) debitur dapat memberi kuasa kepada kreditor dengan hak substitusi. Maka menurut UUHT, Surat Kuasa Membebankan Hak Tanggungan (SKMHT) tidak boleh memuat kuasa substitusi yaitu penggantian penerima kuasa melalui pengadilan. Namun jika penerima kuasa memberikan kuasa kepada pihak lain dalam rangka penugasan untuk bertindak mewakilinya. Misalnya, Direksi Bank menugaskan pelaksanaan kuasa yang diterimanya kepada Kepala Cabangnya atau pihak lain, maka ini bukan merupakan substitusi (Penjelasan Pasal 15 ayat (1) huruf b).

b. Pembatasan Jangka Waktu

Guna mencegah berlarut-larutnya pemberian kuasa dan terjadinya penyalahgunaan serta demi tercapainya kepastian hukum, maka berlakunya SKMHT

${ }^{7}$ Yudo Paripurno,1996, Pengaturan dan pelaksanaan Surat Kuasa memasang Hipotik (SKMH) dalam kaitannya dengan UU Hak Tanggungan, Jakarta, Makalah UI Depok. Hal. 6 dibatasi jangka waktunya. Untuk hak atas tanah yang sudah terdaftar, wajib diikuti dengan pembuatan APHT selambat-lambatnya 1 (satu) bulan sesudah diberikan. Sedangkan, terhadap hak atas tanah yang belum terdaftar harus dipenuhi dalam waktu 3 (tiga) bulan. Yang dimaksud tanah yang belum terdaftar adalah tanah-tanah yang hak kemilikannya telah ada menurut Hukum Ada, tetapi proses administrasi dalam koncersinya belum selesai dilaksanakan (Penjelasan Pasal 10 ayat (3)). Jadi, merupakan hak atas tanah yang berasal dari konversi hak lama yang telah memenuhi syarat untuk didaftarkan, tetapi pendaftarannya belum dilakukan.

Mengenai bentuk SKMHT ini juga telah ditentukan dalam Lampiran Peraturan Menteri Negara Agraria/Kepal Badan Pertanahan Nasional Nomor 3 Tahun 1996. Dalam Surat Menteri Negara Agraria/Kepala BPN tanggal 18 April 1996 Nomor 110-1039 sebagai pengantarsekaligus penjelasan Peraturan Menteri Negara Agraria/Kepala BPN Nomor 3 tahun 1996 disebutkan bahwa penggunaan blanko SKMHT yang baru ini, baru berlaku mulai tanggal 1 Agustus 1996. SKMHT yang dibuat sejak tanggal 9 April 1996 sampai saat diterimanya Surat Edaran dan Peraturan di atas, tetap dapat digunakan sebagai dasar pembuatan Akta Pemberian Hak Tanggungan, dengan ketentuan dalam Akta Pemberian Hak Tanggungan yang dibuat oleh PPAT harus tetap memenuhi ketentuan dalam Undang-Undang Hak Tanggungan. SKMHT yang dibuat sesudah tanggal 1 Juni 1996 sampai sebelum 1 Agustus 1996, PPAT atau Notaris dalam membuat SKMHT tersebut harus mencontoh bentuk SKMHT yang sudah ditetapkan dalam peraturan tersebut.

\section{B. Akibat Hukum Penerbitan SKMHT}

Dalam praktek sehari-hari pembuatan SKMHT dibuat guna menjadi jembatan untuk 
mewujudkan pembuatan APHT dikemudian hari dikarenakan pada saat itu APHT belum dapat dibuat sehingga terpaksa dibuat SKMHT lebih dahulu, misal pada saat pembuatan akta perjanjian kredit seharusnya dilanjutkan dengan pembuatan APHT namun karena sertipikat sedang dalam proses peralihan hak atau sedang dalam proses peroyaan menyebabkan APHT tidak dapat dibuatkan saat itu. Bila kreditur setuju maka saat itu dibuat saja akta perjanjian kredit dan SKMHT sedangkan APHT akan dibuatkan dikemudian hari yaitu setelah proses peralihan atau proses peroyaan selesai.

SKMHT memberikan kedudukan yang kuat kepada kreditur karena SKMHT tidak dapat ditarik kembali dan dan tidak dipergunakan atau karena telah habis jangka waktunya. Oleh sebab itu kreditur tidak perlu merasa khawatir akan kekuatan SKMHT, yang perlu diperhatikan adalah masa berlakunya SKMHT karena SKMHT akan gugur demi hukum bila masa berlakunya berakhir. Disarankan agar PPAT mempunyai daftar atau catatan khusus tentang semua SKMHT yang dibuatnya sehingga mudah dikontrol untuk mengetahui kapan berakhirnya masa berlaku SKMHT yang dibuatnya. SKMHT yang telah berakhir masa berlakunya tidak dapat dipergunakan lagi sebagai alas hak untuk membuat APHT bila hal ini terjadi maka dapat menimbulkan kelemahan/potensi kerugian pada kreditur. Harus diingatkan bahwa SKMHT yang telah habis masa berlakunya menyebabkan SKMHT gugur demi hukum dengan demikian dapat disimpulkan bahwa masa berlaku SKMHT tidak dapat diperpanjang oleh karena itu PPAT harus sungguh-sungguh memperhatikan dan memperhitungkan masa berlakunya SKMHT sehingga menghindarkan diri dari tidak dapat dibuatnya APHT yang dikarenakan telah berakhirnya masa berlakunya SKMHT.

\section{Kendala-kendala dalam pelaksanaan SKMHT dalam perjanjian utang-iutang} khususnya di kota Denpasar.

Kendala pada pembuatan SKMHT khususnya oleh Notaris / PPAT yang membuat SKMHT tersebut secara yuridis tidak ditemukan. Hal ini dikarenakan pengaturan mengenai SKMHT telah jelas diatur dalam UUHT, akan tetapi hambatan tersebut ditemukan pada pengurusan secara administratif yaitu pada proses penggunaan SKMHT menjadi APHT dan besarnya biaya yang diperlukan dalam pensertifikatan objek SKMHT yang belum terdaftar. Menurut keterangan dari Ida Ayu Dwipayatni,SH, Notaris/PPAT di Kota Denpasar, bahwa Dimana, dalam pelaksanaan nya SKMHT yang memiliki jangka waktu 3bulan (Pasal 15 ayat (4) UUHT) tidak cukup waktu untuk sampai pada tahap pemasangan APHT, dan konsekuensinya apabila telah lewat waktu maka SKMHT tersebut akan batal demi hukum. Akibatnya kreditur tidak memiliki hak untuk mengeksekusi jaminan yang diberikan debitur bila wanprestasi, dan debitur tidak mendapatkan biaya yang diperlukan dalam usaha bisnisnya. Hal ini dapat menimbulkan kerugian bagi kedua belah pihak.

Lebih lanjut menurut keterangan beliau bahwa dalam prakteknya terhadap tanah yang belum bersertifikat / terdaftar, setelah SKMHT ditandatangani maka proses yang sering menjadi hambatan adalah pensertifikatannya. Hal ini dikarenakan proses tersebut memerlukan waktu yang lama (biasanya lebih dari 3 bulan) dan juga biaya yang cukup besar. ${ }^{8}$ Hambatan-hambatan tersebut dapat dilihat pada table berikut ini :
${ }^{8}$ wawancara dengan Ida Ayu

Dwipayatni,SH, Notaris/PPAT di Denpasar. 


\begin{tabular}{|l|l|l|}
\hline No & Hambatan-hambatan & Jumlah \\
\hline 1 & Biaya yang mahal & 15 \\
\hline 2 & $\begin{array}{l}\text { Jangka waktu yang } \\
\text { singkat }\end{array}$ & 35 \\
\hline 3 & Tidak ada hambatan & - \\
\hline & Jumlah & 50 \\
\hline
\end{tabular}

Sumber : data primer

Berdasarkan tabel diatas, ternyata biaya menjadi salah satu hambatan peningkatan SKMHT menjadi APHT. Hal itu bukan karena biaya peningkatan SKMHT menjadi APHT oleh PPAT, namun karena proses selanjutnya yaitu pensertipikatan terhadap objek SKMHT yang belum terdaftar tersebut memerlukan biaya yang mahal. Sedangkan terhadap SKMHT lainnya yang tidak mengalami hambatan tersebut berlaku pasal 15 ayat (5) UUHT. Hal ini berdasarkan jumlah masingmasing kreditnya tersebut, dimana tidak perlu mentaati jangka waktu berlakunya surat kuasa, dalam hal untuk menjamin kredit tertentu yang diterapkan peraturan perundang-undangan, seperti kredit kecil, kredit kepemilikan rumah, dan lain-lain (Peraturan Menteri Negara Agraria/Keputusan Badan Pertanahan Nasional No. 4 tahun 1996 tentang penjelasan batas waktu penggunaan SKMHT untuk menjamin pelunasan kredit-kredit tertentu), yaitu sampai berakhirnya masa berlakunya perjanjian pokok yang bersangkutan. Dalam prakteknyaterhadap tanah yang belum bersertipikat/terdaftar, setelah SKMHT ditandatangani maka proses yang sering menjadi hambatan adalah pensertipikatannya. Hal ini dikarenakan proses tersebut memerlukan biaya yang cukup besar.

Berdasarkan hasil wawancara dengan Ida Bagus Subawa,SH,MKn, Notaris/PPAT di Kota
Denpasar ${ }^{9}$, berkaitan dengan ketentuan jangka waktu SKMHT terhadap hak atas tanah yang telah terdaftar dalam prakteknya tidak ditemui kendala untuk ditindaklanjuti dengan APHT, sebaliknya terhadap hak atas tanah yang belum terdaftar dalam praktek tidak dapat terealisir dengan baik karena waktu yang diberikan tersebut tidak mencukupi kekurangan waktu tersebut terletak pada proses pesertipikatan hak atas tanah, sehingga proses pembuatan APHT mengalami pengunduran waktu.

Dengan ketentuan mengenai jangka waktu berlakunya SKMHT yang singkat sedangkan jangka waktu perjanjian kredit lebih lama dari ketentuan tersebut, maka akan merugikan pihak kreditor. Karena tidak mustahil, bahwa kredit sudah menjadi macet sekalipun kredit baru diberikan belum tiga bulan. Kemacetan itu dapat terjadi bukan oleh karena analisis kreditor terhadap kelayakan usaha yang akan diberikan itu tidak baik, tapi kemacetan itu dapat terjadi sebagai akibat perubahan keadaan ekonomi atau perubahan peraturan yang terjadi. Bila terjadi perubahan keadaan tersebut, sudah tentu debitor akan enggan untuk memberikan SKMHT baru bila SKMHT yang lama telah habis jangka waktu berlakunya. Oleh karena itikad baik debitor melihat peluang untuk dapat mengelak dari tanggung jawabnya untuk membayar kembali hutangnya atau berusaha mengulurulur waktu. Debitor akan berusaha mencegah bank dapat membebani hak tanggungan diatas tanah yang telah diagunkan untuk kreditnya.

b. Upaya-upaya dalam mengatasi kendalakendala pelaksanaan SKMHT dalam perjanjian utang-piutang khususnya di

\section{Kota Denpasar.}

Menurut keterangan I Gede Perdana Artha, SH, MKn, Notaris/PPAT di Kota Denpasar, dalam mengatasi kendala-kendala yaitu biaya

${ }^{9}$ Wawancara dengan Notaris/PPAT Ida Bagus Subawa,SH,MKn, Notaris/PPAT di Kota Denpasar. 
yang mahal dan jangka waktu yang singkat dapat dilakukan dengan memperbaharui SKMHT. Sebagaimana telah dikemukakan berdasarkan pasal 2 PMNA/KBPN No.4 tahun 1996 bahwa jangka waktu SKMHT untuk tanah yang belum ada sertipikatnya adalah sampai terbitnya sertipikat ditambah 3 bulan harus segera dibuatkan APHT. Dalam prakteknya walaupun pendaftaran hak atas tanah yang belum ada sertipikat sudah selesai, dan sudah lewat 3 bulan sejak diterbitkannya sertipikat hak atas tanah tersebut, akan tetapi tidak segera dibuat APHT adalah karena biaya baik yang resmi maupun yang tidak resmi untuk pembebanan hak tanggungan tersebut sangat mahal, sementara itu jangka waktu pelunasan kredit sudah hampir selesai. ${ }^{10}$ Menurut keterangan dari I Ketut Suyasa, SH, Legal Officer PT.Bank Tabungan Negara (Persero) Tbk Cabang Denpasar, berdasarkan kesepakatan dengan kreditor, para debitor yang tidak membuat APHT tersebut cukup membuat SKMHT yang baru sebagai pengganti SKMHT yang lama yang sudah habis jangka waktunya. Tindakan ini dilakukan kreditor demi kepentingan debitor itu sendiri, kreditor tidak ingin memberatkan debitor untuk menanggung biaya yang mahal tersebut. Disamping itu dapat dilakukannya pembaharuan SKMHT karena pihak kreditor tidak mengalami kesulitan dalam menyertakan kembali pihak debitor untuk ikut serta menandatangani SKMHT. Hal itu dikarenakan kreditor dalam memberikan kredit kepada semua debitor tidak secara keseluruhan tetapi secara rekening Koran yaitu kredit diberikan bertahap berdasarkan waktu pemberian kredit yang telah diperjanjikan. Sehingga apabila debitor ingin meminta lagi kredit yang tersisa, sedangkan jangka waktu SKMHT yang telah berakhir, maka bank

${ }^{10}$ wawancara dengan I Gede Perdana Artha, SH, MKn, Notaris/PPAT di Denpasar. meminta debitor untuk menandatangani SKMHT yang baru. ${ }^{11}$

Terhadap SKMHT yang ditingkatkan menjadi APHT tersebut dilakukan berdasarkan kesepakatan antara kreditor dengan debitor dikarenakan jumlah kredit yang dikeluarkan jenis kredit komersial. Terhadap tanah-tanah yang dipasang dengan SKMHT, kemudian ditingkatkan menjadi APHT yang berada diluar wilayah kerja kreditor dan pembuatan APHT tersebut dilakukan dengan mengirim SKMHT yang dibuat diwilayah kerja kreditor kepada kreditor di wilayah kerja berdasarkan SKMHT yang dikirim tersebut. Terhadap tanah yang belum terdaftar, setelah sertipikat hak atas tanah dikeluarkan, maka berdasarkan SKMHT dilakukan pembuatan APHT, kemudian selanjutnya dilakukan pembebanan hak tanggungan terhadap objek SKMHT tersebut menjadi hak tanggungan. Dalam pembuatan APHT debitor tidak ikut menandatangani APHT. Namun APHT tetap dapat didaftarkan ke Kantor Pertanahan dengan melampirkan SKMHT yang telah ditandatangani sebelumnya oleh debitor.

\section{SIMPULAN DAN SARAN.}

\section{A. Simpulan}

1. pembebanan hak tanggungan untuk tanahtanah yang sudah terdaftar (ada sertipikat) didahului dengan pembuatan APHT oleh PPAT, yang kemudian berdasarkan APHT tersebut oleh Kantor Pertanahan dikeluarkan sertipikat hak tanggungan. Untuk tanahtanah yang belum terdaftar dan tanah-tanah yang berada diluar wilayah kerja kreditor, pembebanan hak tanggungannya adalah dalam bentuk SKMHT yang juga dibuat oleh Notaris/PPAT. Dalam praktek, meskipun sertipikatnya dikantor pertanahan telah lewat masa 3 bulan, tidak segera

\footnotetext{
${ }^{11}$ wawancara dengan I Ketut Suyasa,SH, Legal Officer PT. Bank Tabungan Negara (Persero) Tbk Cabang Denpasar.
} 
dibuat APHT. Oleh debitor dengan persetujuan kreditor, hanya dibuat SKMHTyang baru sebagai pengganti SKMHT yang telah berakhir jangka waktunya.

2. Hambatan-hambatan yang timbul pada saat pembuatan dan peningkatan SKMHT menjadi APHT yaitu biaya peningkatan SKMHT menjadi APHT karena proses pensertipikatan terhadap objek SKMHT yang belum terdaftar tersebut memerlukan biaya yang mahal. Begitu pula terhadap jangka waktu yang singkat menjadi permasalahan berikutnya. Hal ini dikarenakan jangka waktu perjanjian kredit lebih lama dibandingkan jangka waktu berlakunya SKMHT serta proses pensertipikatan hak atas tanah yang belum terdaftar.

3. Upaya-upaya yang dilakukan dalam mengatasi hambatan-hambatan tersebut yaitu dengan memperbaharui SKMHT yang telah habis masa berlakunya. Dengan demikian, untuk mengatasi kedua hambatan tersebut hanya dapat dilakukan pembaharuan SKMHT sambil menunggu proses pensertipikatan objek SKMHT yang belum terdaftar tersebut. Setelah sertipikat hak atas tanah dikeluarkan, maka berdasarkan SKMHT dilakukanlah pembebanan hak tanggungan terhadap objek SKMHT tersebut menjadi objek hak tanggungan..

\section{B. Saran-saran}

1. Perbuatan hukum ini telah dilakukan sesuai dengan peraturan-peraturan perundangundangan yang berlaku. Namun hendaknya para pihak khususnya kreditor agar mempertimbangkan penggunaan SKMHT dalam hal debitor meminjam kredit, karena perbedaan dari segi fungsi antara SKMHT dan APHT, perbedaan dari segi jangka waktu berlakunya maupun tentang perbedaan kedudukan kreditor pada SKMHT dan APHT. Sehingga kreditor dapat menilai apakah nilai kredit tersebut sesuai bila digunakan SKMHT atau langsung dengan APHT.

2. Hendaknya diperhatikan oleh pemerintah tentang pengaturan biaya SKMHT menjadi APHT yang dirasakan para pihak sangat memberatkan sehingga dengan adanya perubahan dikemudian hari akan mempelancar proses pemasangan SKMHT menjadi APHT serta akan mewujudkan pensertipikatan terhadap tanah-tanah yang belum terdaftar. Kemudian perlu diperhatikan oleh pemerintah tentang jangka waktu SKMHT yang dipasang khususnya terhadap tanah yang belum terdaftar , dimana dalam UUHT hanya memberikan batas waktu hingga 3 (tiga) bulan agar memberikan kelonggaran waktu terhadap proses pensertipikatan objek SKMHT yang belum terdaftar tersebut atau pihak Kantor Pertanahan mampu menyelesaikan sesuai dengan batas waktu SKMHT yang telah ditentukan UUHT.

3. Pembaharuan SKMHT memang diperlukan, namun hal itu tidak perlu terus dilakukan apabila adanya suatu peraturan yang mengatur mengenai perpanjangan SKMHT khususnya terhadap tanah yang belum terdaftar. Terhadap upaya lain berupa proyek Nasional Agraria hendaknya akan membantu para pihak dalam hal biaya dan waktu. Namun hal tersebut dapat terjadi apabila pihak Kantor Pertanahan dengan serius menjalankan prosedur yang telah ada. 


\section{DAFTAR ISI}

Adrian Sutedi,2012, Hukum Hak Tanggungan, Jakarta, Sinar Grafika. Hal.93-94.

Habib Adjie, 2008. Hak Tanggungan Sebagai Lembaga Jaminan atas Tanah, Bandung, Mandar Maju, hal. 6.

Satjipto Raharjo, 2000, Ilmu Hukum, Bandung, PT.Citra Aditya Bakti .hal. 53.

Yudo Paripurno,1996, Pengaturan dan pelaksanaan Surat Kuasa memasang Hipotik (SKMH) dalam kaitannya dengan UU Hak Tanggungan, Jakarta, Makalah UI Depok. Hal. 6 